\title{
Ammobium and Nablonium (Asteraceae-Gnaphalieae) - an alternative view
}

\author{
A.E. Orchard
}

\begin{abstract}
Orchard, A.E.* (Tasmanian Herbarium, GPO Box 252C, Hobart, Tasmania, Australia 7001) 1992. Ammobium and Nablonium. (Asteraceae-Gnaphalieae) - an alternative view. Telopea 5(1): 1-12. The transfer of Nablonium to Ammobium by Anderberg (1990) is re-examined in light of additional characters. Some of the characters used by Anderberg to link Nablonium with Ammobium craspedioides are shown to be based on misinterpretations. Nablonium differs from the two species of Ammobium by a group of 14 characters, while the links between the genera are much less than previously suggested. These relationships are best reflected in a classification which keeps the two genera distinct.
\end{abstract}

\section{Introduction}

The genus Nablonium, endemic to Tasmania, and consisting of a single, well-defined species, has always been difficult to place within the tribal subdivisions of the Asteraceae. At various times it has been placed in the Anthemideae, Heliantheae and Inuleae. Within the Inuleae it has been assigned to the Bupthalminae, Angianthiinae and Gnaphaliinae. The taxonomic history has been surveyed by Anderberg (1990) and a full account can be found there.

Anderberg (1990) has recently compared Nablonium with Ammobium, the two species of which occur in eastern mainland Australia. On the basis of a limited number of characters he concluded that the three taxa were congeneric. This synonymy was retained in a later cladistic analysis of the Tribe (Anderberg 1991). He has thus performed a valuable service in finally finding a secure tribal resting place for Nablonium in the Gnaphalieae. However, his claim of congenericity has led me to a closer examination of a wider range of characters, and a conclusion that, while Ammobium and Nablonium are in all likelihood indeed closely related, their relationship is better described by their retention as two genera, rather than combining them into one.

\section{Anderberg's choice of outgroup}

Anderberg (1990) chose to use Cassinia as the outgroup for his cladistic analysis. In retrospect this may have been an unfortunate choice. In his 1991 analysis of the whole tribe, Anderberg arrives (Fig. 12) at a tree which demonstrates that not only is the sister group of his Ammobium s.l. the genus Basedowia, but that Cassinia is just one member of a group of essentially shrubby or arborescent taxa which branch off as a distinct group at a relatively high level of the cladistic tree. It is also interesting to compare his Fig. 8 with Fig. 12 in the same paper and to note how the topology of the tree changes in the vicinity of Cassinia/Ozothamnus/Ixodia when more groups are added to the analysis. With a tree as unstable as this it is not unreasonable to suggest

* Present address: ABRS, GPO Box 636, Canberra, ACT, Australia 2601. 
that if Anderberg had used a different outgroup (e.g. Basedowia or Raoulia) in his initial analysis of Nablonium and Ammobium, then the result may have been quite different.

However, it seems to me that a potentially far greater source of error lies in his interpretation and choice of characters, and this aspect is examined in the balance of this paper.

\section{Re-examination of Anderberg's characters}

Anderberg used only 10 characters in his detailed comparison of the taxa. Most of these were found to exist in two states within Ammobium/Nablonium and his chosen 'sister group' the Cassinia generic complex, although one had three states and another four.

The Anderberg characters were:

1. Life Form. The outgroup, Cassinia and its relatives (including Helichrysum subgenus Ozothamnus, Ixodia, Odixia, and Haeckeria), are shrubs or small trees almost without exception. Ixodia, while woody, might be considered a perennial herb, but in fact behaves also as a shrub, albeit short-lived. Nablonium and Ammobium on the other hand are not in the least shrub-like, being rosette-forming perennial herbs. In this respect they more closely resemble many of the other genera of the Gnaphalieae (Gnaphalium, Helipterum, Helichrysum s.lat. excluding Ozothamnus, etc.). Hence, if they do indeed belong to the Cassinia 'clade' then they either represent a reversion from the woody growth habit or, as seems more likely, have retained the ancestral form while the rest of the group has become frutescent.

2. Stem Branching. The taxa of the Cassinia 'clade', being shrubby, necessarily have a branching habit. In addition, the inflorescence usually consists of a very complex compound structure, comprising dozens or hundreds of individual heads, usually aggregated into an umbelliform structure at the apex of the main and secondary branches. In Nablonium/Ammobium the structure is again as one would find in, for example, the herbaceous members of Helichrysum s.lat. A single stem arises from a rosette, and this forms the flowering scape. In Ammobium alatum it is sparingly branched towards the top, and each branch bears a flower head. In Ammobium craspedioides it is very similar, but unbranched with just a single capitulum. Nablonium also has an unbranched scape in most cases, although occasional plants, presumably those in which the growing apex has been damaged, will sometimes bear a forked scape with two capitula. I believe that in the scoring of this character there has been confusion between two non-homologous structures. The outgroup has branched vegetative stems, as well as a branched inflorescence. Ammobium and Nablonium species all have unbranched stems, $A$. alatum has a branched inflorescence, and $A$. craspedioides and Nablonium have unbranched inflorescences (apart from occasional freaks). This single character is thus better treated as two, vegetative branching, and branching of the scape.

3. Leaves decurrent in stems (scapes). The scape in A. alatum is strongly winged, and the cauline leaves or bracts are certainly decurrent with these wings. $A$. craspedioides has an angled scape, and the bracts are more or less decurrent, particularly near the base of the plant. Nablonium usually lacks bracts on the scape, but when one is occasionally present it has a broad, sub-winged 'petiole'. However the scape itself is approximately round, and there is little sign of any decurrence. This latter state seems to be the general condition in most of the 'outgroup' although in a few species (e.g. Ixodia), the leaves are decurrent in stem wings. However, the Nablonium situation would 
seem to be representative of the ancestral form, in the Cassinia clade at least, with $A$. craspedioides forming an intermediate stage in a transformtion series to the winged stems/decurrent leaves of $A$. alatum. On this hypothesis, winged stems would have arisen more than once within the clade.

4. Presence of a rosette. There is an element of double counting in this character, in that it is largely accounted for already by character number 1. Obviously the shrubby outgroup, by virtue of being frutescent, cannot have leaves in basal rosettes.

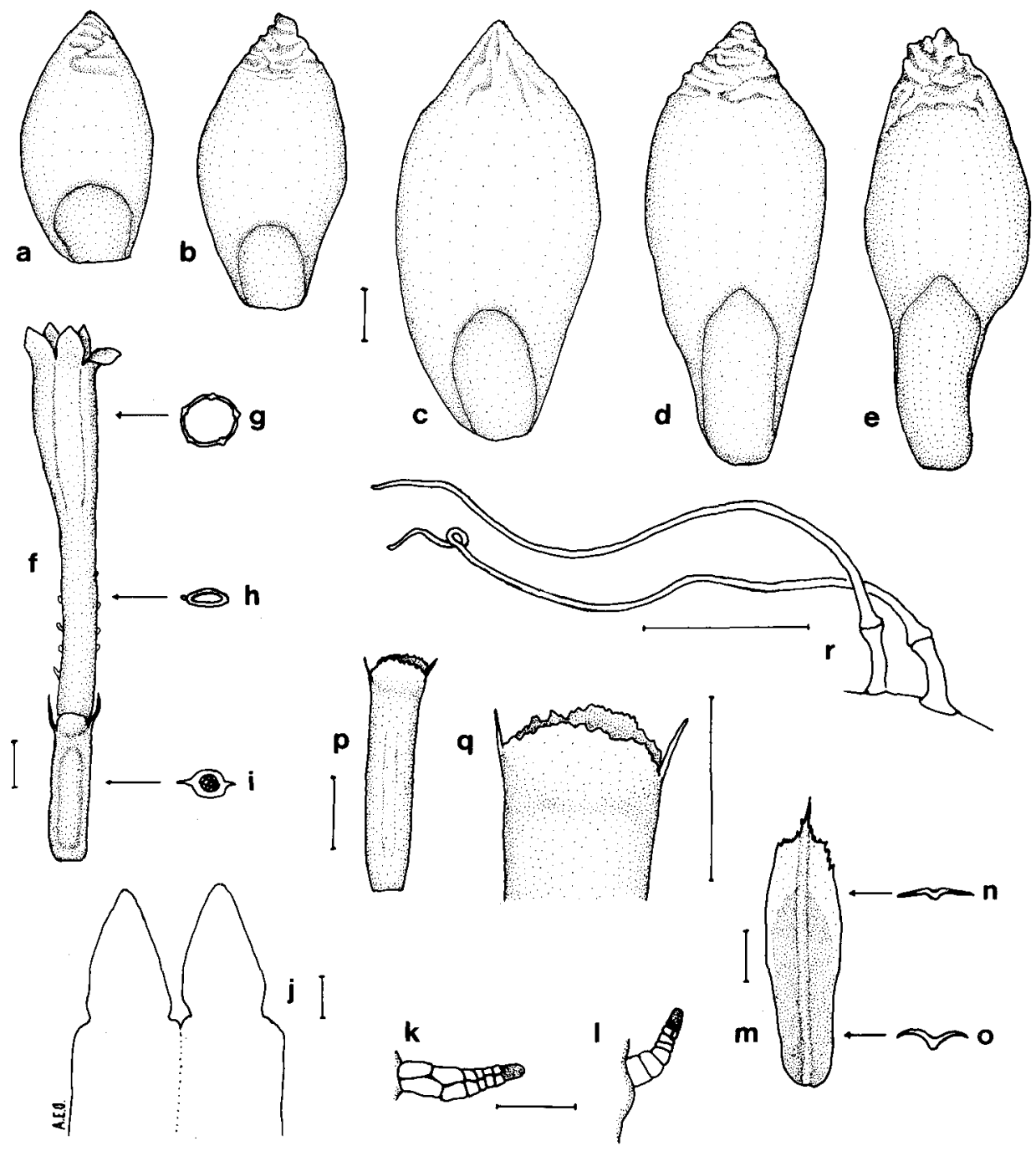

Figure 1. Ammobium alatum. a-e, involucral bracts, a range from outer to inner; $\mathbf{f}$, floret; $\mathbf{g}-\mathbf{i}$, transverse sections of the floret; $\mathbf{j}$, anther appendages; $\mathbf{k}, \mathbf{l}$, glandular hairs on the corolla tube ( $k$, seen from the front, showing the double row of cells; 1 , seen from the side, both with the terminal vesicle shed); $\mathbf{m}$, palea from the receptacle of a fruiting head; $\mathbf{n}, \mathbf{o}$, transverse sections of the palea; $\mathbf{p}$. ripe achene; $\mathbf{q}$, detail of the top of the achene, showing the cup formed from the chartaceous ligule; $\mathbf{r}$, hairs of the leaf. (a-e, j, m-r from J.H. Maiden s.n., HO 9700; $\mathrm{f}-\mathrm{i}, \mathrm{k}-1$ from I.R. Telford 10002, HO. Scales represent $1 \mathrm{~mm}$ in all cases except $\mathrm{j}-\mathrm{l}, \mathrm{r}$, where they represent 0.1 $\mathrm{mm}$ ). 
5. Capitula few or many. This character seems to me to have been used already in character number 2 . As already stated, the branching treated there confused vegetative branching with branching in the inflorescence. Only if these are separated can character 5 be considered a separate character.

6. Involucral bracts tawny or white. Anderberg considered that $A$. alatum had white involucral bracts while the other two species had 'tawny' bracts. This distinction overlooks the facts that the tawny bracts of $A$. craspedioides and Nablonium are quite different in shape and structure, and can scarcely be considered homologous. In the outgroup, and in both Ammobium species the involucral bracts are scarious, with a relatively small basal stereome and a large more or less hyaline wing, which may or may not be coloured (and therefore opaque). In Nablonium the involucral bracts are entirely (outer bracts) or almost entirely (inner bracts) sub-fleshy, with at most a scarious margin. In herbarium material they may appear dry and tawny but in life, or when soaked up, they are clearly fleshy. There are also differences in general shape, which will be discussed further below. The involucral bracts of the two Ammobium species differ only in colour, being structurally virtually identical, and thus far from providing a means of separating A. craspedioides and Nablonium from $A$. alatum, as Anderberg's analysis would suggest, in fact provide good reason to keep the two Ammobium species distinct from Nablonium.

7. Paleae entire or lacerate. Despite Anderberg's assertion to the contrary, these bracts in at least some of the outgroup (e.g. Cassinia aculeata, the type species of that genus) are lacerate at the apex, even if only slightly so. Certainly they are distinctly lacerate in both species of Ammobium and in Nablonium. These bracts in fact provide a good set of characters to keep the three taxa together, as a distinct transformation series can be constructed in their form and function. This will be discussed further below. However, if this attribute is redefined as paleae not or only slightly lacerate vs. paleae distinctly lacerate, then it provides an additional character to distinguish the Ammobium/Nablonium group from Cassinia and the other frutescent genera.

8. Colour of the disc florets. Within the Ammobium/Nablonium group this character provides a useful distinction. Ammobium species have yellow florets, Nablonium has white ones. The latter is the character state found most frequently in the outgroup. Even in species like Cassinia aureo-nitens, which has bright golden yellow involucral bracts, the flowers are white or off-white. Other Cassinia species however have cream or yellow flowers.

9. Shape of the achene. Anderberg scored the achene of A.craspedioides as being 'stout', i.e. as having a diverging apex, as in Nablonium, rather than being elongate as in $A$. alatum. I find that the distinction is not as clear cut as this. While the outer achenes in the heads of $A$. craspedioides may have slightly divergent apices, it is not quite as marked as he claims. The inner achenes are elongate as in $A$. alatum (Figs. 1p, 2l). To some extent, the shapes of the achenes are linked to the next character, the size of the spines, as these influence the outer shape of the fruit. It would be better to redefine this character in terms of the relative length and breadth of the achene (excluding the spines), if in fact it is useful at all. If the character became 'Achene up to twice as long as broad (excluding spines)' vs. 'Achene more than twice as long as broad', then the two Ammobium species are distinguished from Nablonium.

10. Size of achenial spines. This character, and the presumed transformation series from small spines to large in the direction A. alatum - A. craspedioides - Nablonium seems to be the central thesis in Anderberg's paper. He advanced the view that the cup at the top of the achene in the three species was essentially the same strucure, and that it had been modified from one to the next by an increase in the size of the spines. This view, if correct, would provide strong evidence for linking the three taxa 
into one genus. Unfortunately, after a careful study of the structure of the cup and spines of each species, I cannot agree that all represent homologous structures. In the two Ammobium species the cup is formed from a membranous, obtuse 'ligule'. These two lips are confluent in a notch at either side of the achene, and the spines arise at this notch. In Nablonium the cup is barely apparent in the bud or young flowering stage (Fig. 3d). It is formed at the late flowering/fruiting stage by confluence of the woody bases of the spines. This is shown, particularly in the outer fruits of the capitulum, where on one side there is a distinct notch where the spine bases have not fused completely (Figs. 3e, 3j). In fruits where there is no notch, the cup splits easily at the midpoint between the spines, at a line of weakness. There are other differences
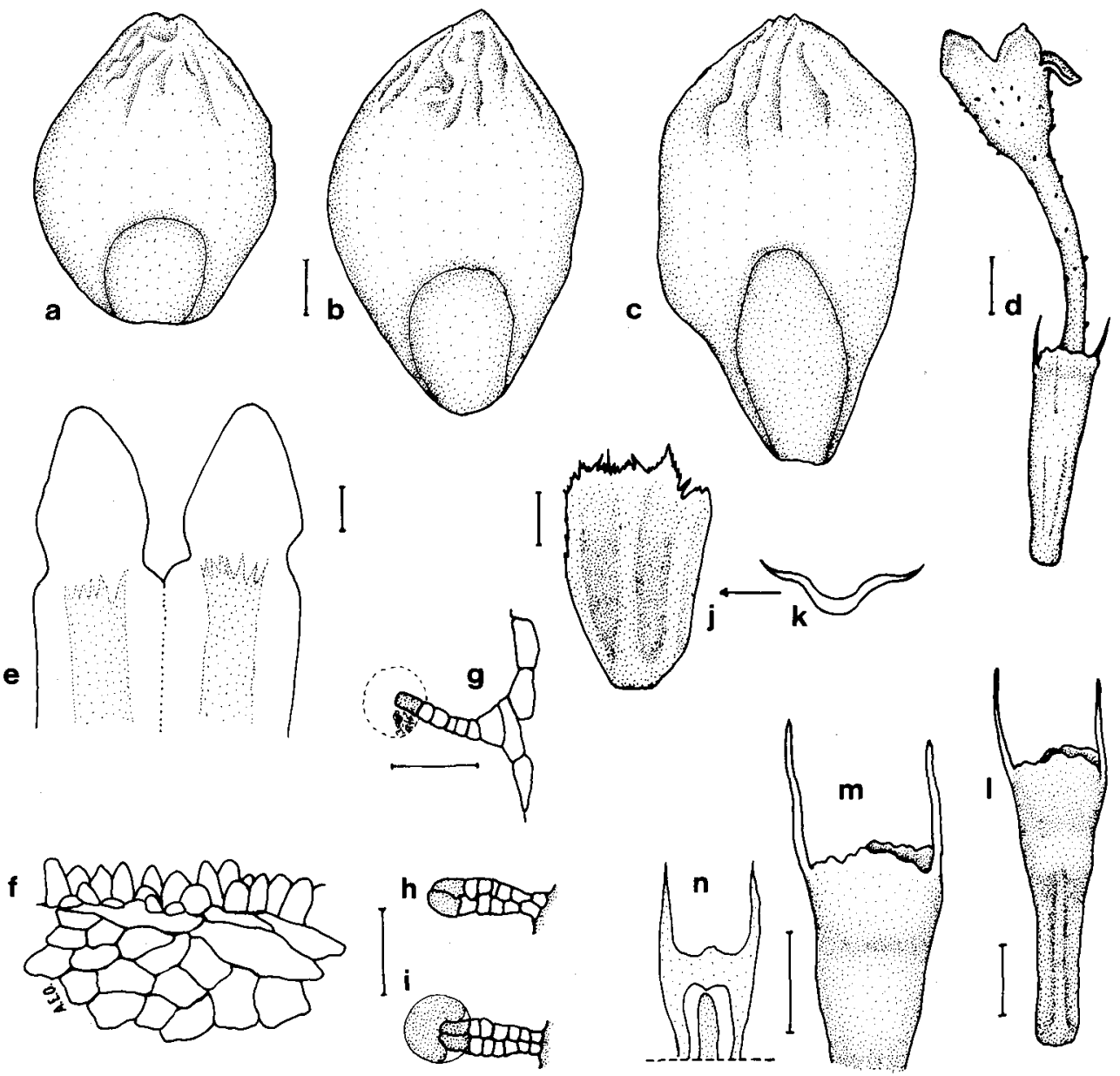

Figure 2. Ammobium craspedioides. a-c, involucral bracts, a range from outer to inner; $\mathrm{d}$, floret; e, anther appendages; $\mathbf{f}$, edge of a petal showing papillae; $\mathbf{g}-\mathbf{i}$, glandular hairs on the corolla tube (i showing the terminal vesicle complete, $g \& h$ with the vesicle burst); $j$, palea from the receptacle of a fruiting head; $\mathbf{k}$, transverse section of the palea; 1 , mature achene; $\mathbf{m}$, detail of the top of the achene showing the cup formed from the chartaceous ligule; $\mathbf{n}$, transverse section through the walls of the cup. (a-k from M.M. Richardson \& G. Butler 351a, HO; l-n from I.R. Telford \& A.M. Lyne 11001, HO. Scales represent $1 \mathrm{~mm}$ in all cases, except $\mathrm{e}-\mathrm{i}$, where they represent $0.1 \mathrm{~mm})$. 
in the shape of the spines, and in the structure of the cup wall, which suggest that the Ammobium species are much more closely allied to each other than to Nablonium in this series of characters also. These characters are discussed in the next section. Thus while the presence of spines on the achene provides a strong link binding this group of three species together, in contrast to the more normal pappus found in the outgroup, I believe it may be misleading to score the spine size and associated cup structure as a transformation series in the way proposed by Anderberg.

\section{Other characters not used by Anderberg}

Perennation: Anderberg noted in his text that Nablonium proliferated by stolons, but this character did not form part of his analysis. Both of the Ammobium species lack stolons, propagating themselves by seed only, as do the taxa in his outgroup.

Leaf indumentum: The leaves of Ammobium alatum are densely clothed on both surfaces by loose cottony hairs, consisting of 1-2 short basal cells with swollen junctions and a long tapering terminal cell (i.e. similar to Drury \& Watson's (1966) Type A hairs) (Fig. 1r). Those of Ammobium craspedioides have similar cottony hairs on their lower surface, but on their upper surface bear a completely different kind of indumentum. The hairs are spreading, uniseriate, and composed of several short, broad, thin-walled cells. On drying these hairs collapse onto the leaf surface. In Nablonium there are no cottony hairs on the leaves. Instead both surfaces bear the second type of hair mentioned above, with numerous large thin-walled cells. These are sparse on the upper surface of the Nablonium leaves, and usually dense on the lower surface, and when they collapse they form a dense white matted layer (Figs. 3n-s). On wetting, they swell once again to their previous shape and become spreading. Cottony hairs in Nablonium are confined to a sparse covering on the scape.

Scape characters: In Nablonium the scape is more or less circular in section, and usually lacks bracts (cauline leaves). Rarely, in very robust specimens, there may be a single bract on the scape. It has a broad \pm winged 'petiole' but is not decurrent. In A. craspedioides the scape is angled, and the bracts $(2-6)$ are decurrent. In A. alatum the scape is strongly 4-winged, and the bracts (2-6) are strongly decurrent into the wings. In all three species the scape is covered in cottony hairs.

Involucral bracts: The involucral bracts of Nablonium are sub-fleshy, ovate, with an acute or shortly attenuate tip, and a scarious tawny-hyaline margin (Figs. 3a-c). The involucral bracts of both species of Ammobium are scarious throughout, with a relatively small basal stereome and large membranous lamina (Figs. 1a-e, 2a-c). In both the lamina is blunt at the tip (the bracts often obovate to spathulate in shape), coloured white (opaque) in $A$. alatum, and tawny-hyaline in $A$. craspedioides. In both species of Ammobium the involucral bracts are usually wrinkled at the tips. The inner involucral bracts in $A$. alatum may be narrowed at the base to form a \pm distinct claw. The taxa of Anderberg's outgroup have bracts most closely resembling those of Ammobium in all of these characters.

Florets: The corolla tube in Nablonium is white and glabrous. In both species of Ammobium it is yellow, and bears stalked glandular hairs both on the tube and the outer surface of the lobes. These hairs consist of two parallel rows of small \pm cubic cells topped by two larger elongate cells (Figs. 1k-1, 2g-i). These apical cells exude a golden resinous substance which is contained at first in a thin-walled envelope. This later bursts, releasing the resin. As the hairs dry and age the small cells of the stalk shrivel and collapse. The inner surfaces of the corolla lobes in A. craspedioides bear a dense covering of tiny papillose hairs (Fig. 2f). These are also present in $A$. alatum, but are not quite so obvious or widespread. In Nablonium they are absent. Stalked glandular hairs on the corolla are common in Cassinia. 
Anther appendages: In both species of Ammobium the sterile appendages at the tips of the anthers are broad (about as wide as the individual anthers), ovate and blunt (Figs. 1j, 2e). In Nablonium, they are much narrower, approximately lanceolate to deltoid in shape, and acute (Fig. 3g).

Paleae: The receptacular bracts in Nablonium are broadly oblong, and distinctly lacerate at the top (Fig. $3 \mathrm{~h}$ ). They are frequently coloured reddish purple. Throughout the development of the flower and fruit they remain membranous, and they are overtopped by the mature achene. In $A$. craspedioides the receptacular bracts are similar to those of Nablonium, but as the fruit develops they become woody, and cradle
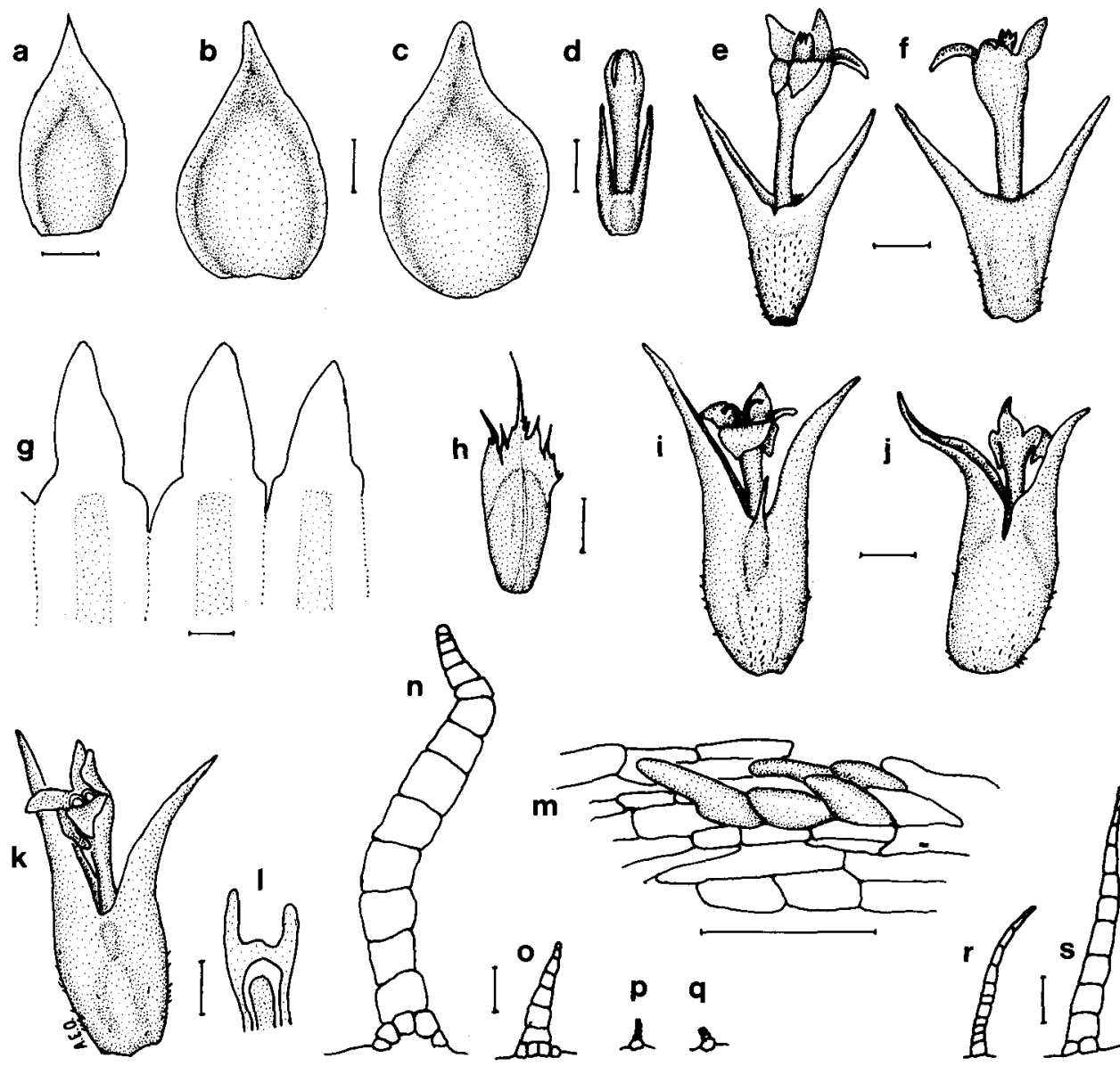

Figure 3. Nablonium calyceroides. a-c, involucral bracts, a range from outer to inner; d, bud; e, f, floret, the two sides of the same floret (e showing the notch where the spine bases have not fused properly); $\mathbf{g}$, anther appendages; $\mathbf{h}$, palea from the receptacle of a fruiting head; $\mathbf{i}, \mathbf{j}$, two sides of the same achene, one with a short notch, the other with a short auxilliary spine; $\mathbf{K}$, another achene with more normal smooth cup margin; 1 , transverse section through the subwoody cup of the achene shown as $k ; m$, a group of 5 papillate hairs from the surface of the achene; $\mathbf{n}-\mathbf{q}$, hairs from the upper surface of the leaf; $\mathbf{r}, \mathbf{s}$, hairs from the lower surface of the leaf. (All from A.E. Orchard 5708, HO. Scales represent $1 \mathrm{~mm}$ in all cases, except $\mathrm{g} \& \mathrm{k}-\mathrm{s}$, where they represent $0.1 \mathrm{~mm}$ ). 
the ripening achene in their concave inner face, thus affording it protection against predation up to and beyond maturity (Fig. 2j). In A. alatum this transformation series is taken a step further. The bract, from an early stage, is sub-woody, becoming very woody at maturity. It is lacerate at the top, but not as much as the other two species (Fig. $1 \mathrm{~m}$ ). Instead it develops a strong woody spine at the tip. These woody, spined paleae are retained on the plant long after the achenes have matured, forming an effective 'hedgehog', amongst which the ripe achenes are retained and protected. Here it would seem are two convergent methods that have been developed for protection of the achenes. In Nablonium the spines on the fruit are robust and effectively provide their own protection. In Ammobium craspedioides the lightly woody paleae provide some mechanical protection, which is supplemented by moderate-sized spines on the fruits themselves. In $A$. alatum the fruit spines are of little effective value for protection, but their function has been replaced by the heavily sclerised pungent paleae. The transformation series must be read from the membranous paleae (the situation in Nablonium and Anderberg's outgroup) to the increasingly woody ones. The spine development could be read in the opposite direction (from small spines in A. alatum to large spines in Nablonium), and this is the way it was interpreted by Anderberg. However, as shown below, this may be a misinterpretation.

Achene indumentum: Anderberg stated that the achenes of all three species were glabrous. While this is true for the Ammobium species, the achenes of Nablonium bear in their lower half $\mathrm{a} \pm$ dense indumentum of unicellular papillose hairs (Fig. $3 \mathrm{~m}$ ).

Spines of the fruit: Anderberg proposed a transformation series from the tiny spines of $A$. alatum to the massive spines of Nablonium. However, careful study of the spines and the associated ligule or cup at the top of the achenes shows that the spines of Nablonium are quite different from those of the other two species. In Nablonium the spines are sub-woody, and have a groove along their upper surface, making them U$Y$ shaped in section. At the base the two wings of the ' $U$ ' are confluent around the top of the achene, forming a shallow cup with massive sub-woody walls (Figs. 3i-1). In the two Ammobium species the spines are not only shorter, but much less substantial. They are circular in cross section and the cup is formed, not by confluence of the spines, but by a separate structure, a membranous 'ligule' which is present even in quite young buds (Figs. 1p-q, 2l-n). The cup in Ammobium is therefore membranous when the flower is young, and may become chartaceous in a mature achene, but is never sub-woody. The margin of the cup in Nablonium is thick and rounded, in $A$. crasspedioides it is membranous and undulate, and in $A$. alatum, membranous and erose. As mentioned above, there may be a transformation series discernible in the spines of these species. However, from their different structure, the spines of Nablonium should be excluded from it, and their development considered separately. The transformation series probably runs from the generalised medium spines of $A$. craspedioides, which have a protective function, to the tiny spines of $A$. alatum which have lost this function to the spinous paleae, and are now only vestigial. This series runs in the reverse direction to that proposed by Anderberg.

The characters mentioned above, along with those of Anderberg, are summarised in Table 1 (pp. 680-681).

\section{Conclusions}

Consideration of the characters in Table 1 indicates that the Ammobium/Nablonium group is quite distinct from the Anderberg outgroup, and further, that the two Ammobium species have far more in common with each other than either does with Nablonium. The character states defining the outgroup, genera and species are summarised below. 


\section{Separation of Ammobium/Nablonium from Anderberg's outgroup}

Four independent characters separate Ammobium and Nablonium from the outgroup (character state of the outgroup given in brackets):

Growth form perennial herbs (shrubs or small trees); inflorescence of 1-few heads (inflorescences compound, of many individual heads); paleae distinctly lacerate (paleae not or only minutely lacerate); and achene bearing apical spines (achenes with a pappus of barbed hairs). If the presence/absence of leaves in a basal rosette is considered to be a good character, separate from growth habit, then this provides a fifth point of distinction.

\section{Separation of Ammobium species from Nablonium}

Fourteen independent characters are available to distinguish the two species of Ammobium from Nablonium (character state in Nablonium is given in brackets):

No form of vegetative reproduction (stolons present); leaves with cottony 'Type $\mathrm{A}^{\text {' }}$ hairs (leaves lacking cottony hairs); scape winged or angled (scape round in section); scape with 2-6 bracts (scape lacking bracts, or if present, 1 only on robust plants); involucral bracts membranous with a small basal stereome (bracts subfleshy with a membranous margin and obscure stereome); involucral bracts blunt and wrinkled at the tip (bracts acute to subapiculate and smooth); paleae subwoody to woody (paleae membranous); florets yellow (florets white); florets with glandular hairs on the outside of the tube (florets glabrous); anther appendages broad (anther appendages narrow); achenes linear/cylindric, more than twice as long as broad (achenes short with diverging apex, up to twice as long as broad); spines of the achene circular in section (spines U- to Y-shaped in section); cup at top of achene formed by a special submembranous 'ligule' (cup formed by fusion of woody bases of spines); and achenes glabrous (achenes bearing papillose hairs in lower part).

\section{Separation of Ammobium alatum from A. craspedioides}

Three independent characters satisfactorily separate the two species of Ammobium (the character state of $A$. craspedioides is given in brackets):

Hairs of the upper leaf surface cottony 'Type A', semi-appressed (hairs of upper leaf surface thin-walled, multicellular, spreading); involucral bracts white (involucral bracts tawny-hyaline); paleae with a woody terminal spine (paleae lacerate but lacking a distinct spine).

On this hypothesis, the Ammobium/Nablonium group is seen as a satellite group to the Cassinia outgroup, linked by such characters as the paleae on the receptacle, but retaining more of the ancestral Gnaphalieae characters such as a perennial herb habit with rosette leaves. The two Ammobium species are very closely allied to each other, in characters ranging from vegetative features to those of the inflorescence and fruit, and the internal links are closer than those of either to Nablonium. Both share some character states with Nablonium, although the spines of the achene represent convergence rather than an a priori relationship.

These relationships are best reflected in a classification which maintains the two previous genera, rather than merging them as in Anderberg (1990). 


\section{Character}

Life form

Vegetative reproduction

Vegetative stem branching

Branching within inflorescence/

scape

Scape winged/angled

Bracts on scape

Leaves decurrent

Leaf hairs, upper surface

Leaf hairs, lower surface

Involucral bracts, shape

Involucral bracts, texture

Involucral bracts, colour

Paleae

Floret colour
Cassinia

Shrubs

None

Frequent

Frequent

Usually round

Numerous

Sometimes

None, or sparse cottony (Type A)

Various

Oblong to ovate, obtuse, smooth or wrinkled

Scarious with small stereome

Hyaline, tawny, white, pink or yellow

Scarious, entire to sublacerate

White to yellow

\section{Ammobium alatum}

Perennial herb

None

None

Sparse

Strongly winged

$$
2-6
$$

Strongly

Dense cottony (Type A)

Dense cottony (Type A)

Ovate to obovate/spathulate, obtuse, wrinkled at tip

Scarious with small stereome

White

Woody, shortly lacerate and apiculate

Yellow

\section{Ammobium craspedioides}

Perennial herb

None

None

Unbranched

$$
\text { Angled }
$$

Weakly

Multicellular erect

Dense cottony (Type A)

Ovate to obovate, obtuse, wrinkled at tip

Scarious with small stereome

Tawny/hyaline

Subwoody, lacerate

Yellow
Nablonium calyceroides

Perennial herb

Stolons

None

Unbranched

Round

Usually 0

No

Multicellular erect

Multicellular erect.

Ovate, acute, smooth

Subfleshy, no obvious stereome

Green with hyaline margins

Membranous, lacerate

White 


\section{Character}

Glandular hairs on

corolla tube

Papillae on corolla lobes

Anther appendage

Achene indumentum

Achene shape

Pappus

Spine structure

Cupule

Preferred habitat

\section{Cassinia}

Yes

Absent, or very short

Various

Twin hairs

\pm Cylindrica

Uniseriate, barbellate setae

Dry sclerophyll savannah

\section{Ammobium alatum}

Yes

Present

Ovate, blunt,

as wide as anther

None

Flattened, cylindrical

Two tiny spines

$$
+ \text { 'ligule' }
$$

Subwoody, round in section

Formed from membranous ligules

Dry sclerophyll savannah
Ammobium craspedioides

Yes

Present

Ovate, blunt

as wide as anther

None

I Flattened, cylindrical

Two small spines + 'ligule'

Subwoody, round in section

Formed from membranous ligules

Dry sclerophyll savannah
Nablonium calyceroides

Absent

Lanceolate/deltoid, acute, narrower than anther

Papillose hairs

Flattened, flared at apex

Two large spines

Massive woody, U or $Y$ shaped on section

Formed by fusion of spine bases

Maritime interdunal hollows 


\section{Acknowledgements}

I am most grateful to Mr I.R. Telford who provided me with flowering and fruiting material of the two Ammobium species, and to the Curator of the National Botanic Gardens Herbarium (CBG) for the loan of specimens.

Ms Joy Everett kindly made a number of eminently sensible suggestions for improvements which were much appreciated.

\section{References}

Anderberg, A.A. (1990) Nablonium is a congener of Ammobium (Asteraceae-Gnaphalieae). Telopea 4: 129-135.

Anderberg, A.A. (1991) Taxonomy and phylogeny of the tribe Gnaphalieae (Asteraceae). Opera Botanica 104: 1-195.

Drury, D.G. \& Watson, L. (1966) Taxonomic implications of a comparative anatomical study of Inuloideae-Compositae. American Journal of Botany 53: 828-833.

Manuscript received 14 March 1991

Manuscript accepted 29 January 1992 